\title{
O RIO E A CURVA
}

THE RIVER AND THE CURVE

Recebido: 13/11/2020

Nathalia Ferreira da Cunha ${ }^{1}$

Aceito: 08/06/2021

Na curva do desenvolvimento,

Existia um rio.

Dele todos queriam a água.

Dele também queriam ostras.

Mas na curva desse rio,

Quiseram construir casas,

Quiseram modificar sua forma.

Mudando a sua forma,

Mudaram a sua essência.

Das árvores fizeram-se prédios,

Do Mangue fizeram concreto,

Na curva desse rio se tem muros,

$\mathrm{Na}$ curva desse rio se tem enormes tubos.

Da água cristalina,

Onde crianças tomavam banho,

Onde passavam barcos,

Passam outros objetos,

Nesse rio vivem outros seres,

Nesse rio circula outra água.

Lá na curva desse rio não vejo mais nada

Nem vejo esse rio,

\footnotetext{
${ }^{1}$ Doutoranda em Ciências Ambientais e Conservação - Universidade Federal do Rio de Janeiro/ Programa de Ciências Ambientais e Conservação. Servidora Municipal da Secretaria de Meio Ambiente, Agricultura e Pesca de Rio das Ostras
} 
Nem vejo seu mangue,

Nem suas ostras,

Nem sua água cristalina.

Lá na curva desse rio vejo o desenvolvimento,

Vejo lixo,

Vejo tubos,

Vejo uma água suja caída no leito sofrido.

Lá onde foi aquele rio,

Lá onde tinha a tal curva,

Tem o tal desenvolvimento,

Lá onde falta água,

Onde o ar não é mais fresco,

Lá onde não tem árvores,

Lá onde não tem mais seres,

Tem a paisagem do homem,

Da natureza que ele construiu,

Onde o natural destruiu,

Para semear o tal desenvolvimento.

Lá na curva do que era o rio,

Não tem mais rio. 